\title{
PERANCANGAN SISTEM INFORMASI PENJADWALAN PENGIRIMAN BARANG DIDUKUNG APLIKASI PEMOGRAMAN JAVA
}

\author{
RAHMAT FAUZI, S.Kom, M.Kom \\ Fakultas Teknik dan Komputer, Universitas Putera Batam \\ fauzy@yahoo.com
}

\begin{abstract}
Telah dilakukan penelitian pada CV. Rivan Arca Padang, dimana penelitian ini bertujuan untuk mengoptimalkan kinerja sistem dan pengoptimalan penggunaan database. Dimana masih ditemui beberapa masalah dalam pengolahan data penjualannya.Dalam penelitian dan pengujian sistem, dilakukan dengan beberapa metode yaitu penelitian lapangan, penelitian kepustakaan, dan penelitian laboratorium. Penelitian lapangan dilakukan dengan peninjauan langsung kelapangan ke Kantor CV. Rivan Arca Padang sehingga diketahui langsung mekanisme sistem yang ada. Penelitian kepustakaan dilakukan dengan mempelajari buku-buku yang dapat menambah kajian ilmu bagi sistem dan skripsi. Sedangkan penelitian laboratorium yaitu mengolah data dan membuat program pengolahan data dari hasil penelitian.Oleh karena itu dirancang suatu sistem baru yang bertujuan untuk meningkatkan proses pengolahan data penjadwalan pengiriman barang yang lebih efisien. Dimana dengan waktu yang cepat dan sistem yang lebih baik dapat mempermudah semua pihak dalam melakukan pengolahan data.
\end{abstract}

Keywords: Sistem penjadwalan, Aliran system informasi, JAVA

\section{PENDAHULUAN}

Perkembangan dunia teknologi modern dan adanya penemuan-penemuan baru saat ini banyak mengakibatkan perubahan kehidupan manusia dalam menangani setiap permasalahan yang terjadi yang ada kaitannya dengan proses pembangunan secara menyeluruh. Akibat kemajuan yang dicapai ini telah menghasilkan berbagai teknologi. Salah satu hasil karya dari kemajuan dibidang teknologi adalah komputer.

Komputer adalah suatu alat yang dapat membantu manusia mengolah data untuk menghasilkan informasi agar dapat dipakai sebagai dasar pengambilan keputusan. Kecepatan, kecermatan dan keakuratan, komputer telah mempengaruhi cara pengelolaan perusahaan, baik perusahaan pemerintah maupun perusahaan swasta. Dalam hal ini, komputer jelas lebih cepat melaksanakan pekerjaan dalam pengolahan data serta lebih efisien. Ini disebabkan karena komputer merupakan suatu peralatan elektronik yang jarang mengalami kekeliruan.

Salah satu wujud pemanfaatan komputer secara optimal untuk melakukan manajemen database adalah sistem informasi pada CV.RIVAN ARCA . Pada saat ini CV.RIVAN ARCA memang sudah menggunakan komputer akan tetapi penggunaannya hanya sebatas pada kegiatan- kegiatan yang pokok saja oleh karena itu penulis akan memperbaharui sistem ini dengan memaksimalkan penggunaan komputer dengan sistem informasi yang terstruktur dengan baik.

CV. RIVAN ARCA merupakan suatu perusahaan yang bergerak dalam bidang pendistibusian semen. Dengan dikembangkannya rancangan sistem informasi pada CV. RIVAN ARCA ini, diharapkan CV.RIVAN ARCA dapat memberikan pengolahan data terbaik dengan tersedianya kemudahan-kemudahan dalam melakukan proses pembuatan laporan dan penjadwalan pengiriman barang.

Perancangan sistem baru akan mempermudah perusahaan untuk menyusun penjadwalan pengiriman barang membuatan laporan bahkan menyelesaikan permasalahan lainnya yang menyangkut aktifitas bongkar muat barang.

\section{METODE PENELITIAN}

Analisa terhadap sistem yang sedang berjalan pada CV. Rivan Arca Padang ini dilakukan bertujuan untuk mengetahui bagaimana sistem yang ada pada CV. Rivan Arca Padang dalam melakukan pengolahan data permintaan dan pengiriman barang, apaapa kendala dari sistem yang ada sekarang ini untuk dilakukan perancangan sistem yang baru 
nantinya. Pada CV. Rivan Arca Padang menggunakan metode tidak Terstruktur dimana Metode tidak Terstruktur ini menganggap bahwa barang yang dipesan selalu oleh pelanggan maka itu yang baru dikirimkan meskipun permintaan pelanggan tersebut sama setiap bulan nya. kali.

Metode ini juga mengasumsikan bahwa pemesanan barang akan dikirim sesuai dengan urutan pemesanan tersebut. Pelanggan yang pertama memesan adalah pelanggan yang perama dikirimkan barang begitu juga sebaliknya pelanggan yang terakir memesan maka juga terakir dikirimkan.

Meskipun pada kenyataannya perhitungan itu tidak selalu benar. Apalagi sistem yag digunakan sekarang ini masih bersifat manual sehingga selain memerlukan waktu yang lama dalam pembuatan laporan juga tingkat kesalahan perhitungan akan lebih besar dan ini akan dapat mengakibatkan kerugian yang tidak sedikit bagi perusahaan.

Aliran Sistem Informasi lama merupakan gambaran dari sistem yang sedang berjalan diperusahaan sebelum digunakan atau diterapkanya sistem yang baru.

Dalam sistem informasi yang sedang berjalan ini melibatkan beberapa entity dalam melakukan proses pengolahan data. Adapun entity-entity tersebut adalah pelanggan,supplier,kasir dan pimpinan. Adapun gambaran dari aliran sistem informasi lama pada CV. Rivan Arca Padang adalah sebagai berikut:

1. Pelanggan melakukan pemesanan barang kepada bagian pengiriman

2. Kemudian Bagian Administrasi akan memeriksa ketersediaan barang secara manual yang memerlukan waktu yang cukup lama dan melakukan pengiriman barang

3. Apabila barang telah sesuai, pelanggan melakukan pembayaran kepada Bagian Administrasi / Kasir dan akan proses menghasilkan Faktur Pengiriman barang.

4. Untuk Pembuatan Laporan Pengiriman, Bagian Administrasi terlebih dahulu merekap Faktur faktur pengiriman tersebut secara manual, kemudian akan menghasilkan Laporan pengiriman harian, bulanan.
Untuk lebih jelasnya mengenai Aliran Sistem Informasi yang sedang berjalan pada CV. Rivan Arca dapat dilihat pada gambar 1 berikut ini :

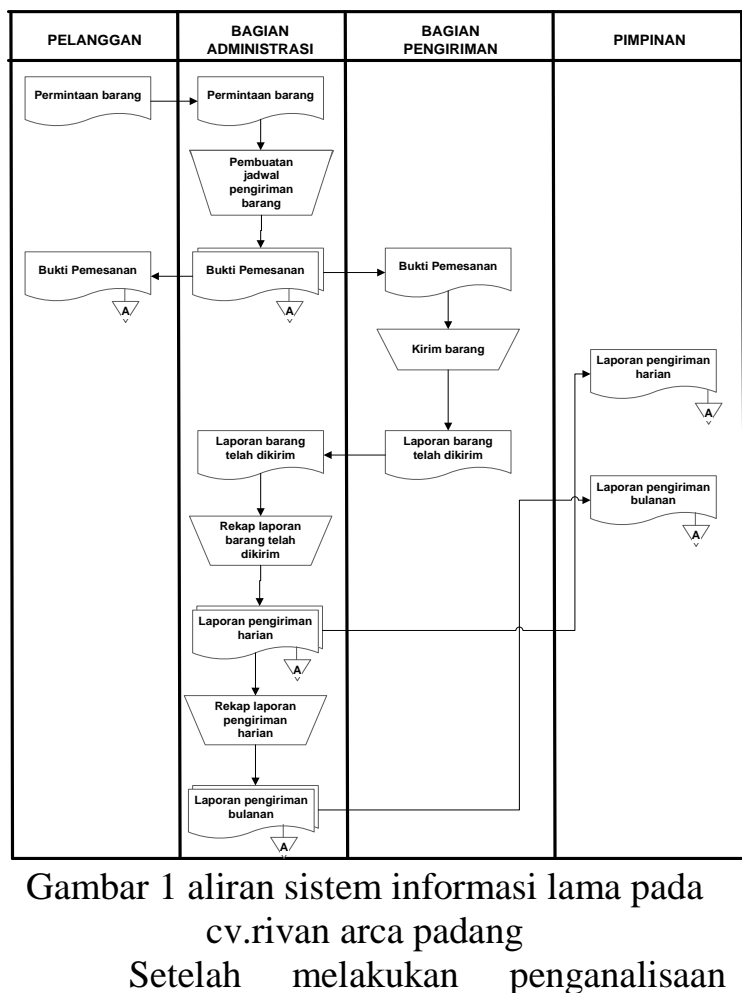
terhadap sistem pengolahan data yang ada pada CV. Rivan Arca Padang maka didapatkan beberapa kelemahan pada sistem informasi pengiriman barang dan persediaan barang pada CV. Rivan Arca Padang. Adapun kelemahankelemahan yang ada pada sistem pengolahan data yang lama ini adalah sebagai berikut :

1. CV. Rivan Arca masih menggunakan sistem manual maka akan mengakibatkan proses pengolahan data yang dilakukan pada CV. Rivan Arca ini menjadi lambat.

2. Media penyimpanan yang masih mengandalkan kertas-kertas arsip meyebabkan kurang terjaminnya data yang tersimpan. Dan sulitnya melakukan pencarian data. Selain itu untuk melakukan penyimpanan data dalam waktu yang relatif lama akan membutuhkan ruang yang banyak.

3. Sulitnya melakukan pencarian data, baik data pengiriman maupun data persediaan barang.

Berdasarkan penganalisaan terhadap sistem yang lama dapat dilihat kelemahan sistem yang ada pada CV. Rivan Arca Padang mengenai pembuatan laporan penjadwalan 
pengiriman barang. Dimana dalam pembuatan laporan masih dilakukan secara manual sehingga tingkat kesalahan pembuatan laporan tersebut relatif tinggi dan tidak adanya efesiensi kerja dalam melakukan proses pengiriman barang. Dengan diterapkannya sistem baru, maka diharapkan bagi analisis melakukan penganalisaan terhadap kebutuhan informasi yaitu berupa output yang dikehendaki dan selanjutnya menganalisa persyaratan yang diperlukan serta menyiapkan data apa saja yang perlu disimpan dalam file. Setelah kebutuhan informasi dan persyaratan tersebut diterapkan, maka tahap selanjutnya adalah tahap perencanaan, antara lain :

1. Merancang dan menerapkan file-file yang dibutuhkan yaitu membuat rancangan data-data sesuai dengan jenis datanya.

2. Merancang sistem secara global.

3. Pembuatan program aplikasi.

Untuk mendesain sistem baru perlu diketahui beberapa hal yang menunjang terjadinya modifikasi sistem yang berlaku sekarang. Dalam hal ini penulis memulai dengan menentukan bentuk keluaran, bentuk masukan dan file-file yang dibutuhkan, serta proses yang terjadi selama sistem berjalan. Diharapkan dengan rancangan sistem baru ini tugas-tugas yang dilaksanakan dapat dikerjakan dengan baik dan informasi yang dihasilkan dapat diperoleh kapan saja oleh pemakai sistem.

Setelah melakukan analisa terhadap sistem pengolahan data pada CV. Rivan Arca, Padang maka penulis melakukan beberapa perubahan - perubahan dalam sistem pengolahan data khususnya dalam proses pembuatan laporan. Dimana pada sistem yang lama dilakukan secara manual dirubah menjadi sistem komputerisasi.

Perubahan-perubahan yang dilakukan dalam aliran sistem informasi pada CV. Rivan Arca Padang dilakukan secara berkala untuk menghindari terganggunya sistem pengolahan data pada CV. Rivan Arca Padang ini. Untuk lebih jelasnya mengenai aliran sistem informasi pada CV. Rivan Arca Padang dapat dilihat pada gambar 2 berikut ini:

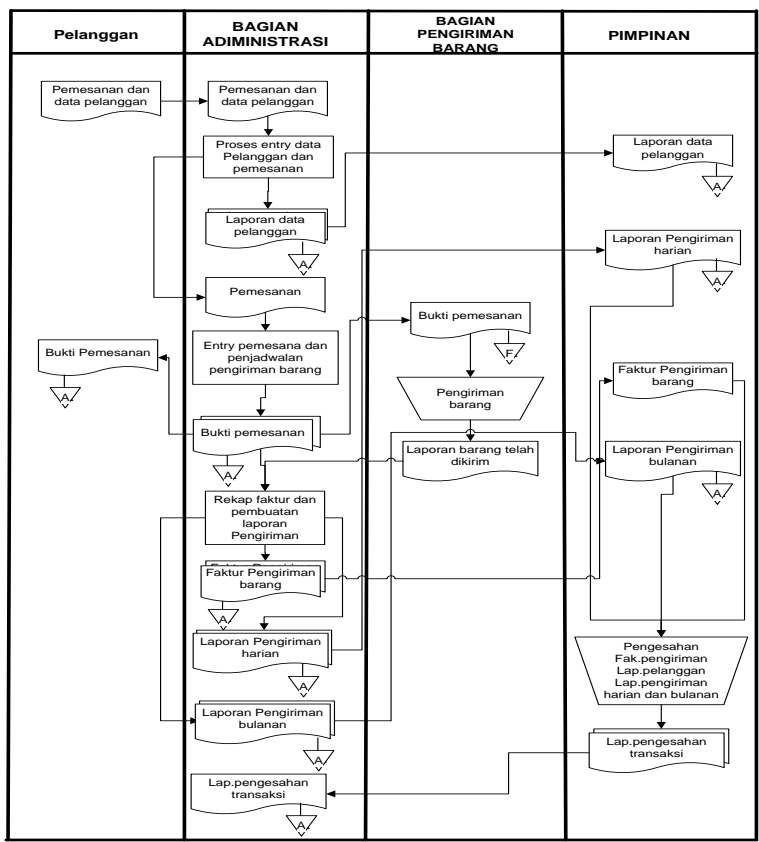

Gambar 2 Aliran Sistem Informasi (ASI Baru)

Pengiriman Barang Pada CV.Rivan Arca

Pada context diagram sistem inventory dan pengeluaran barang pada CV. Rivan Arca ini terdiri dari 4 entity yaitu Pelanggan, Bagian Administrasi Bagian Pengiriman barang dan Pimpinan dimana antara entity-entity ini saling berinteraksi dan berhubungan baik dengan entity yang lain maupun dengan sistem. Untuk jelasnya dapat dilihat pada gambar 3 berikut ini :

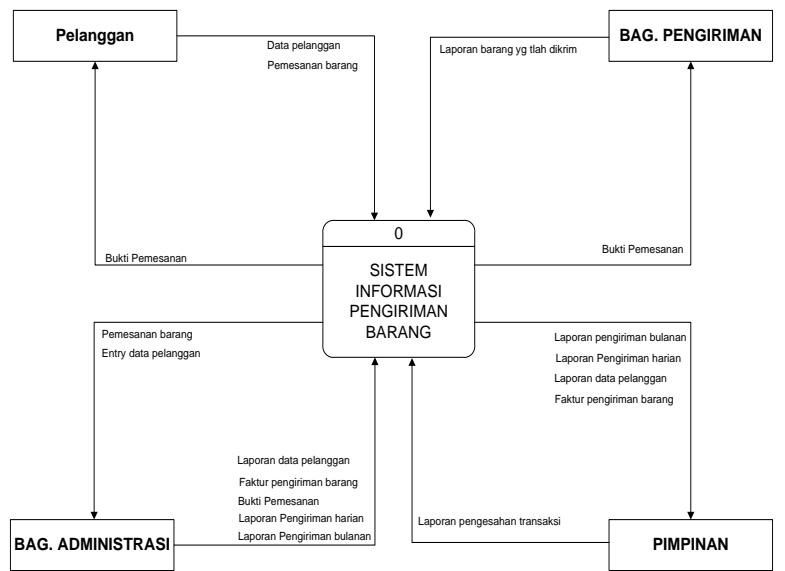

Gambar 3 Context Diagram Pengiriman Barang Pada CV. Rivan Arca

Data Flow Diagram merupakan alat pengembang arus data dalam sistem secara terstruktur dan jelas, dapat dilihat pada gambar 4 berikut ini: 


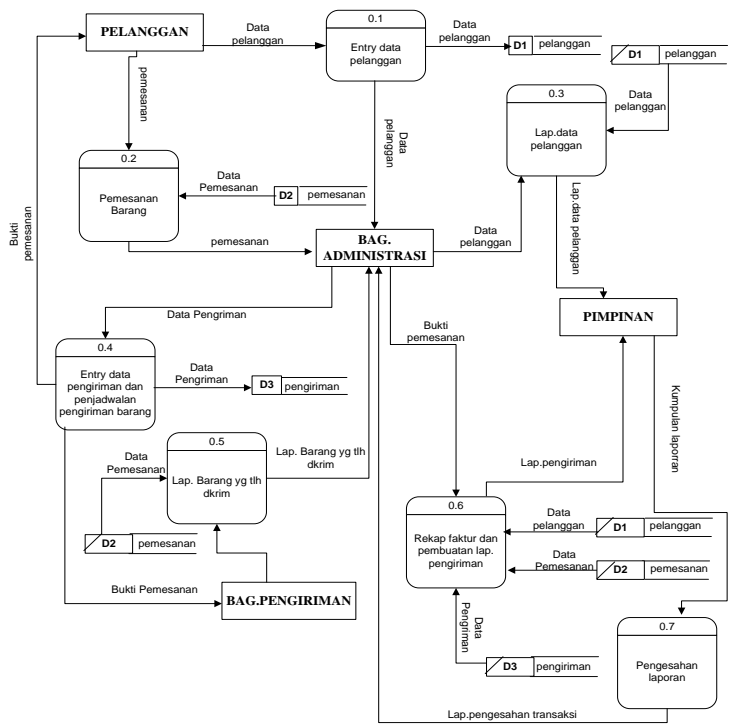

Gambar 4 Data Flow Diagram (DFD) Pengiriman Barang pada CV. Rivan Arca.

Dalam hal ini sebagai penghubung antar databasenya adalah field-field dalam record yang kita set sebagai field kunci (key) yang sifatnya unik (tidak boleh sama dengan yang lain). Berikut ini adalah gambar Entity Relationship Diagram (ERD) CV. Rivan Arca:

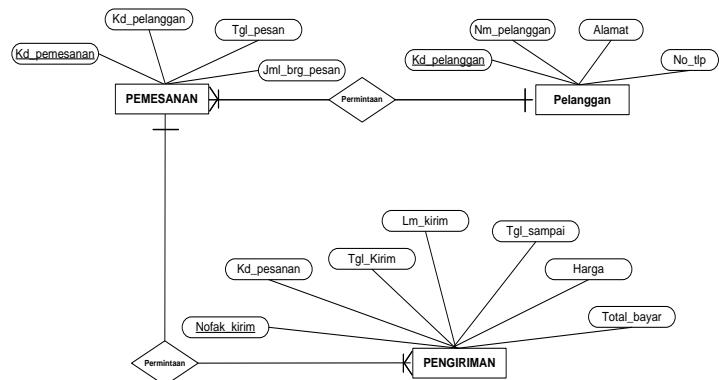

Gambar 5 Entity Relation Ship Diagram

Dalam merancang suatu sistem baru memerlukan suatu sistem aplikasi yang nantinya berguna dalam menjalankan sistem tersebut. Aplikasi ini terdiri dari kumpulan program-program yang saling berinteraksi satu sama lainnya. Untuk dapat mengetahui bentuk dari struktur program yang didesain dalam membantu Sistem Pengolahan Data pengiriman pada CV. Rivan Arca yaitu sebagai berikut :

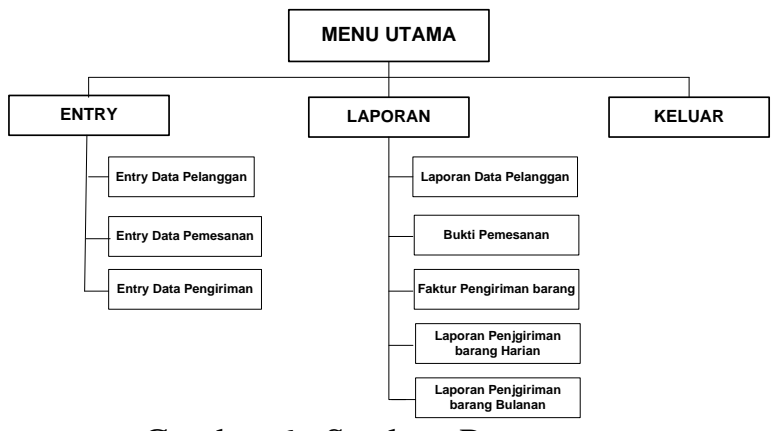

Gambar 6 : Struktur Program

\section{HASIL DAN PEMBAHASAN}

Pada pengujian ini akan dijelaskan mengenai sistem informasi Pengiriman pada Rivan Arca, yang terdiri dari satu bagian menu utama dan beberapa sub menu utama. Bagian menu dari menu utama menjalankan sub-sub menu dalam menu tersebut. Keseluruhan subsub menu tersebut dieksekusi dalam menu utama. Untuk lebih jelasnya dapat dilihat pada gambar 7.

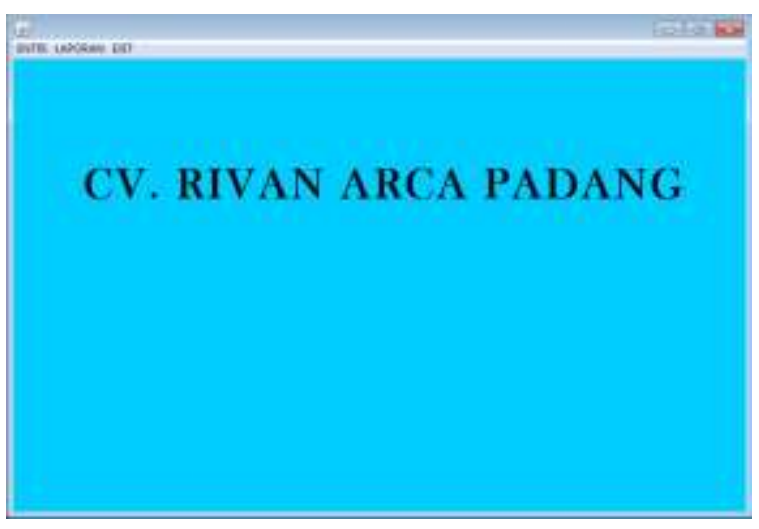

Gambar 7 Menu Utama

Menu utama terdiri dari tiga bagian menu yaitu:

1. Menu Entry Data

Pada menu entry data terdiri dari tiga sub menu:

a. Sub menu entry data pelanggan Menampilkan form menu entry data pelanggan dimana data-data pelanggan akan di input pada form kemudian dimasukkan ke dalam database.

b. Sub menu entry data pemesanan Menampilkan form menu entry data pemesanan dimana data pemesanan akan dimasukkan pada form isian entry data pemesanan 
yang kemudian dimasukkan ke dalam database.

c. Sub menu entry data pengiriman Menampilkan form menu entry data pengiriman dimana data pengiriman akan dimasukkan pada form isian entry data pengiriman yang kemudian dimasukkan ke dalam database.

2. Menu Laporan

Terdiri dari lima sub menu yaitu:

a. Sub menu Laporan Data Pelanggan

Menampilkan laporan data pelanggan dimana form ini berguna untuk menghasilkan Laporan data pelanggan yang ada CV. Rivan Arca Padang .

b. Sub menu Bukti Pemesanan

Menampilkan bukti pemesanan dimana pada from ini berguna untuk menghasilkan bukti pemesanan pada CV.Rivan Arca Padang.

c. Sub menu Faktur Pengiriman

Menampilkan form faktur pengiriman dimana pada from ini berguna untuk menghasilkan faktur pengiriman pada CV. Rivan Arca Padang.

d. Sub menu Laporan Pengiriman Harian

Menampilkan form laporan pengiriman harian dimana pada form ini berguna untuk menghasilkan laporan pengiriman harian pada CV. Rivan Arca Padang.

e. Sub menu Laporan Pengiriman Bulanan

Menampilkan form laporan pengiriman bulanan dimana pada form ini berguna untuk menghasilkan laporan pengiriman bulanan pada CV. Rivan Arca Padang.

3. Menu Exit

Merupakan Sebuah menu untuk keluar dari program apabila telah selesai menggunakan program tersebut.
Dibawah ini beberapa tampilan dari pengoperasian program yang sedang dijalankan

Menu Entry

1. Sub menu Entry Data Pelanggan

Pada entry data Pelanggan ini akan menjelaskan tentang entry data pelangan, pada entry ini didalam form ini menggunakan halhal yang berkaitan dengan data pelanggan untuk yang akan di memesan nantinya. Untuk lebih jelasnya dapat dilihat pada gambar 8 berikut :

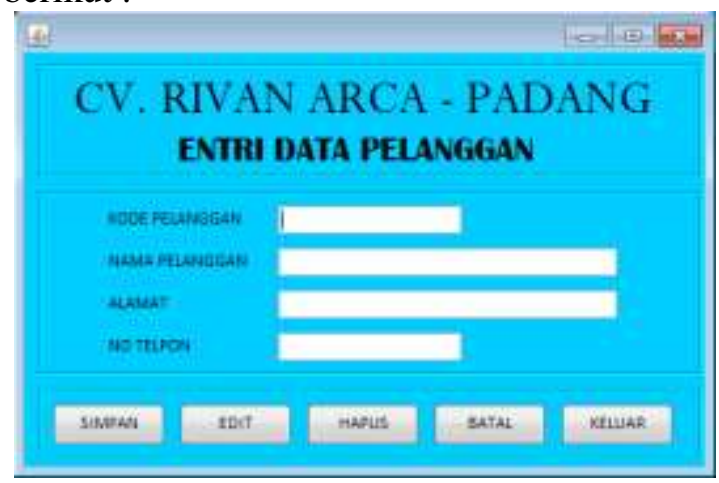

Gambar 8 Entry Data Pelanggan

2. Sub menu Entry Data Pemesanan

Pada entry data pemesanan ini akan menjelaskan tentang entry data pemesanan, pada entry ini didalam form ini menggunakan hal-hal yang berkaitan dengan data pemesanan. Masing masing tombol ini akan tetap digunakan berhubungan dengan fungsi yang dimilki sangat menunjang kegiatan yang dilakukan. Untuk lebih jelasnya dapat dilihat pada gambar 9 berikut :

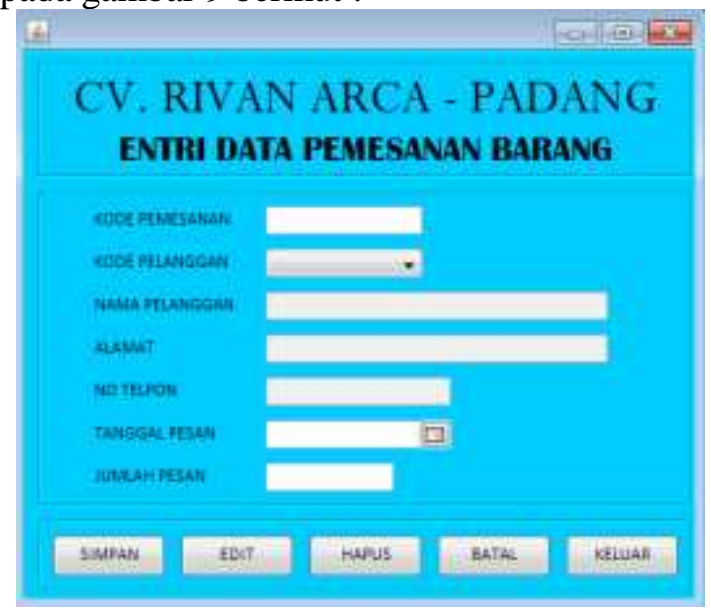

Gambar 9 Entry Data Pemesanan 


\section{Sub menu Entry Data Pengiriman}

Pada entry data pengiriman ini akan menjelaskan tentang input data pengiriman barang pada CV. Rivan Arca Padang, pada entry ini dalam form menggunakan hal-hal yang berkaitan dengan data hasil pengiriman yang telah di lakukan. Data pengiriman yang dihasilkan dari input data yang dilakukan yang akan disimpan kedalam database akan dapat dipanggil dan ditampikan kembali untuk menjelaskan apakah data yang diinputkan telah tersimpan atau tidak. Tombol - tombol yang digunakan adalah save, delete, cancel, cetak dan exit . Masing masing tombol ini akan tetap digunakan berhubungan dengan fungsi yang dimilki sangat menunjang kegiatan yang dilakukan. Untuk lebih jelasnya dapat dilihat pada gambar 10 berikut :

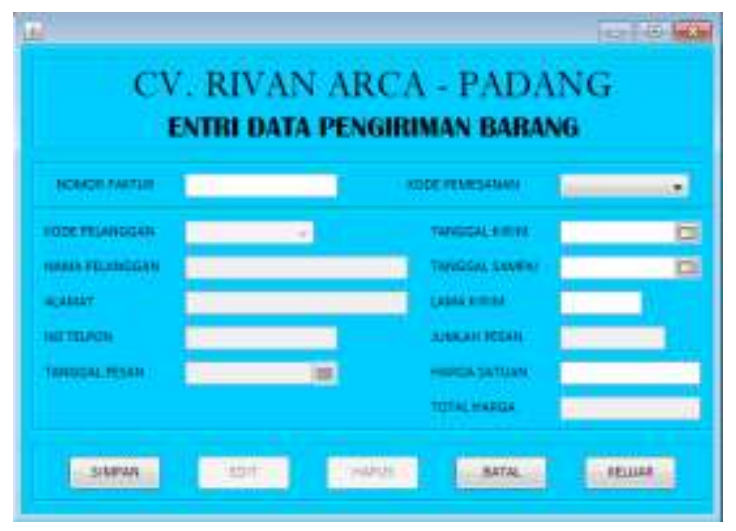

Gambar 10 Entry Data Pengiriman

Laporan Data Pelanggan ini digunakan untuk menampilkan daftar pelanggan yang terdaftar pada CV. Rivan Arca Padang. Untuk proses pembuatannya inputkan nama Pimpinan dan Pilih Tombol Print. Berikut hasil proes pembuatan laporan data pelanggan pada gambar 11 :

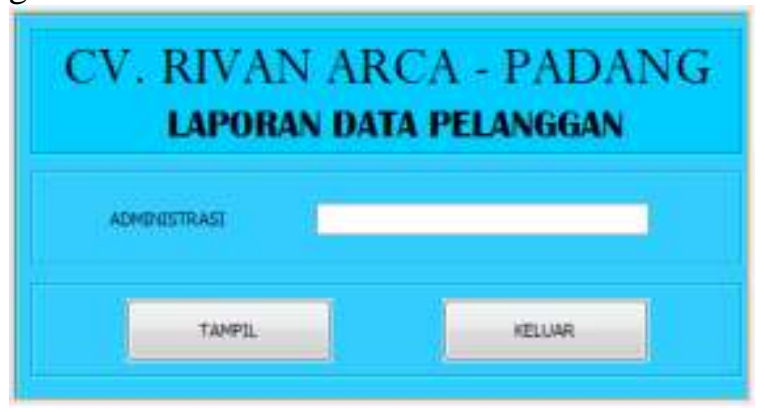

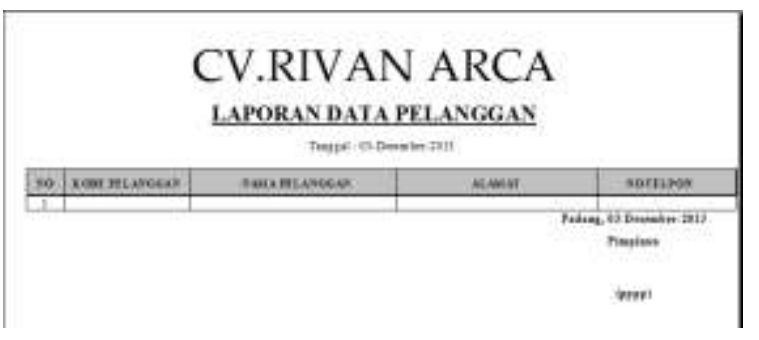

Gambar 11 Laporan Data Pelanggan

Bukti Pemesanan Barang ini digunakan sebagai bukti bahwa pelangan sudah memesan barang pada CV. Rivan Arca Padang. Untuk proses pembuatannya inputkan nama Pimpinan dan Pilih Tombol Print. Berikut hasil proes pembuatan laporan bukti pemesanan pada gambar 12 :
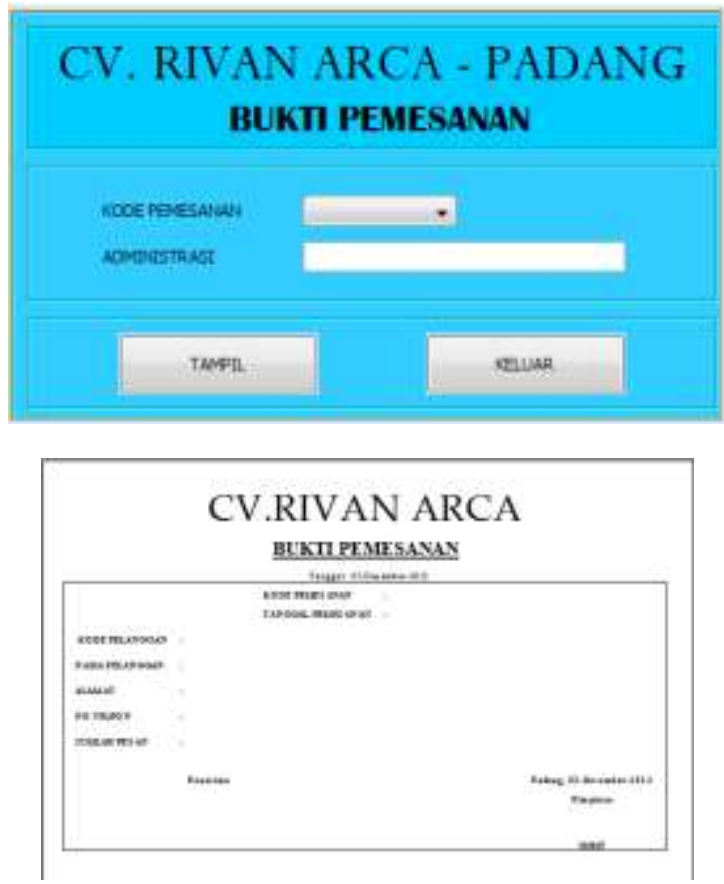

Gambar 12 Bukti Pemesanan

Faktur pengiriman ini digunakan untuk menjelaskan tentang biaya dan jumlah barang yang di kirm kepada pelanggan dan nantinya faktur pengiriman ini akan di cetak dan di serahkan kepada pimpinan untuk mengetahui total harga dan jumlah barang yang telah dikirim pada CV. Rivan Arca Padang. Untuk proses pembuatannya inputkan nomor faktur dan pilih Tombol print. Berikut hasil proes pembuatan faktur pengiriman pada gambar 13 : 

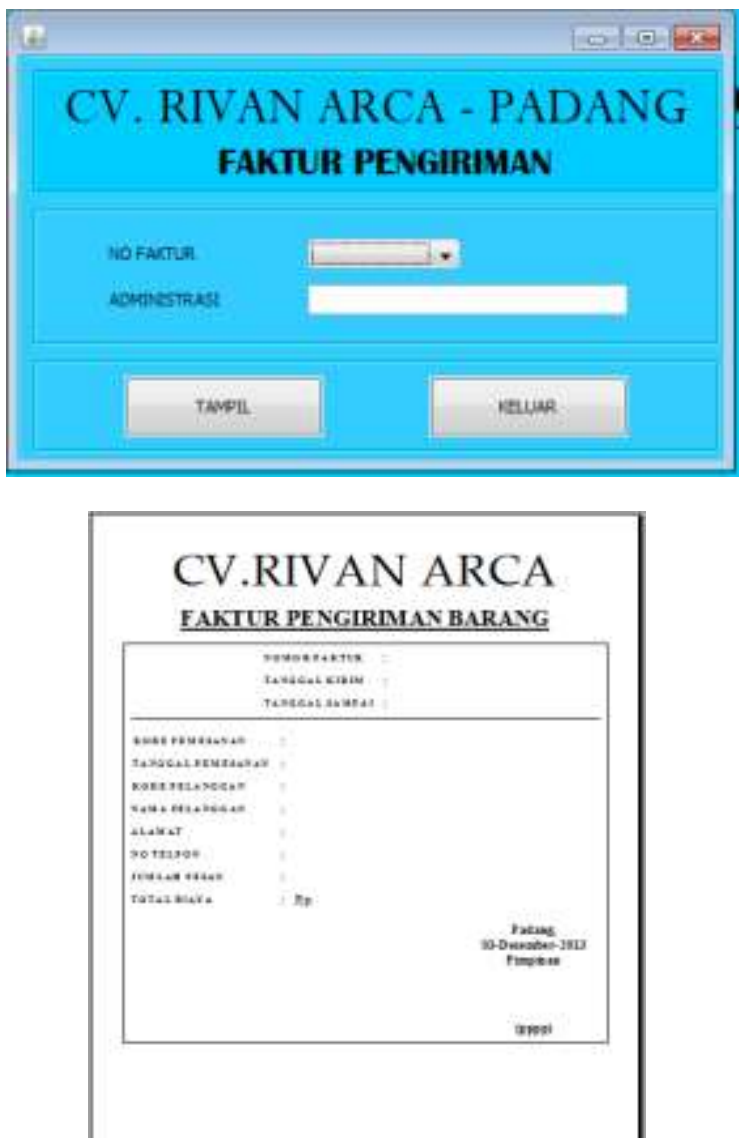

Gambar 13 Faktur Pengiriman

Laporan Pengiriman Harian ini digunakan untuk menjelaskan laporan pengiriman harian yang terjadi pada CV.Rivan Arca Padang, untuk mengetahui berapa jumlah keuntungan per hari yang nantinya akan di perlihatkan kepada pimpinan. Untuk proses pembuatannya pilih tanggal yang akan dijadikan laporan dan inputkan nama Pimpinan. Berikut hasil proes pembuatan laporan pengiriman harian pada gambar 14 :

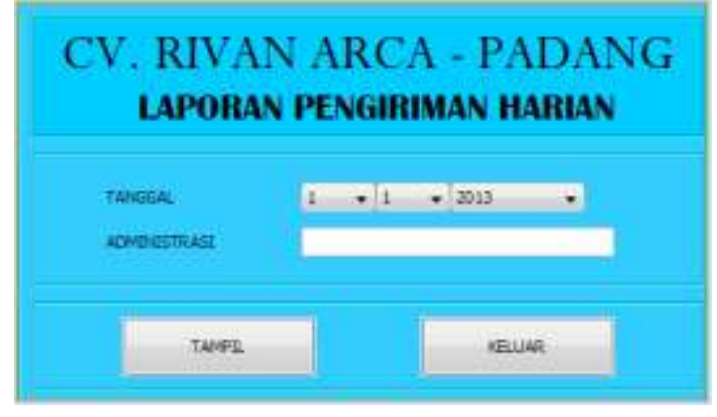

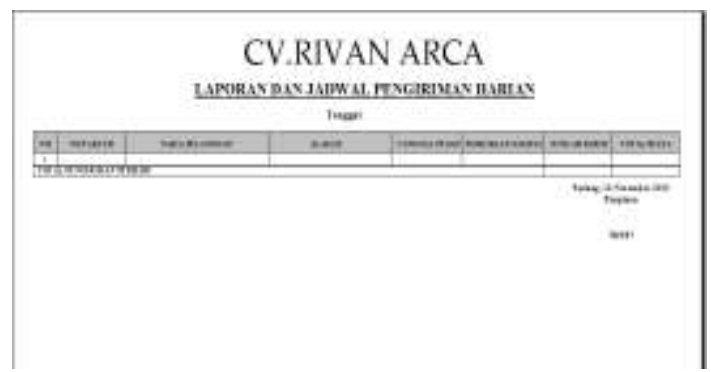

Gambar 14 Laporan Pengiriman Harian

Laporan Pengiriman Bulanan ini digunakan untuk menjelaskan laporan pengiriman bulanan yang terjadi pada CV.Rivan Arca Padang, untuk mengetahui berapa jumlah keuntungan perbulan yang nantinya akan di perlihatkan kepada pimpinan. Untuk proses pembuatannya pilih bulan yang akan dijadikan laporan dan inputkan nama Pimpinan. Berikut hasil proes pembuatan laporan pengiriman bulanan pada gambar 15 :
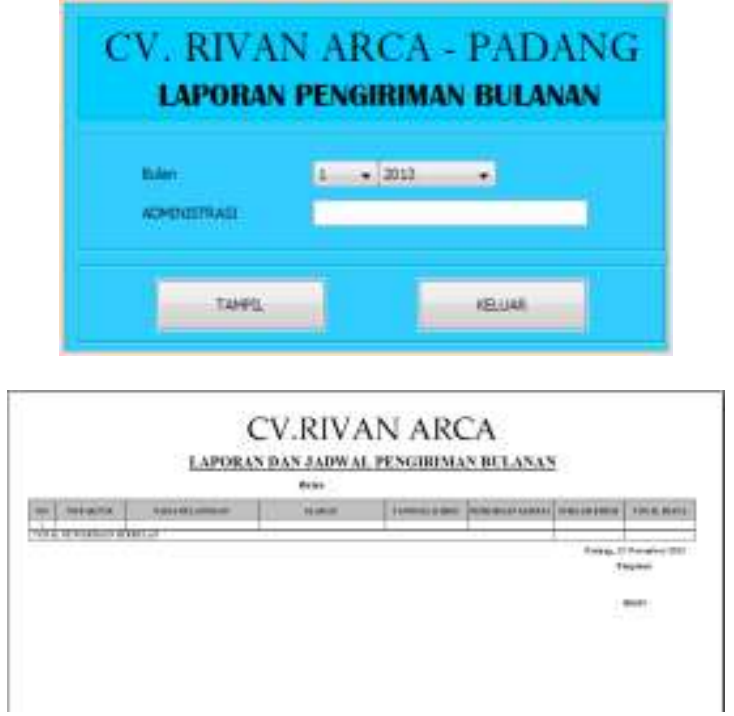

Gambar 15 Laporan Pengiriman Bulanan

\section{SIMPULAN}

Setelah melakukan penelitian pada CV. Rivan Arca Padang dan mempelajari segala aktifitas yang dilakukan dalam pengolahan data pengiriman serta mencoba menganalisa dan menguraikannya kedalam PKL ini, maka dari pembahasan yang telah dilakukan pada sistem pengolahan data pengiriman pada $\mathrm{CV}$. Rivan Arca Padang maka dapat diambil beberapa kesimpulan yaitu :

1. Bahasa Pemrograman Java pada CV. Rivan Arca Padang mampu untuk melakukan pengolahan data pengiriman barang dengan cepat tepat dan akurat 
dan dapat mengurangi proses kerja yang berulang-ulang.

2. Bahasa Pemrograman Java yang di gunakan pada CV. Rivan Arca Padang, mampu memberikan kenyamanan bagi pelanggan.

3. Dengan adanya proses pembuatan laporan yang yang di optimalkan dengan penggunaan komputer, sehingga laporan pengiriman barang dapat disajikan secara cepat tepat dan akurat.

\section{DAFTAR PUSTAKA}

Ir.Yuniar Supardi."5 Sistem Popule dengan Java".Penerbit Alex Media Komputindo, Jakarta :2011

HM, Jogiyanto,"Analisa \& Desain Sistem Informasi". Andi Offset Yogyakarta, Yogyakarta :2005

Kom, HARIYADI S. "Pengembangan Sistem Pakar Berbasis Aturan Untuk Menentukan Mata Kuliah Yang Akan Diambil Ulang (Remedial) Dengan Metode Forward Chaining." Menara Ilmu 10.60-65 (2017).

Kadir, Abdul.’Pengenalan Sistem Informasi”. Penerbit Andi, Jakarta :2003 Prasetyo, Didik Dwi." Belajar Sendiri MySQL", Penerbit PT. Elex Media Komputindo, Jakarta : 2006

Fithgerald, Jerry."Pengertian Sistem".(http://fairuzelsaid.wordpress. com.diakses 10 November,2013). 